\title{
Fish oil-induced milk fat depression and associated downregulation of mammary lipogenic genes in dairy ewes
}

\author{
D. Carreño, G. Hervás, P. G. Toral, ${ }^{1}$ T. Castro-Carrera, and P. Frutos \\ Instituto de Ganadería de Montaña (CSIC-ULE), Finca Marzanas s/n, 24346 Grulleros, León, Spain
}

\begin{abstract}
Several studies in dairy cows have shown a relationship between milk fat depression (MFD) and alterations caused in lipogenic gene expression by dietary nutrients. However, information on small ruminants is not only scarce but also inconsistent. Therefore, this experiment was conducted in dairy ewes to study the effect of a diet known to induce MFD on milk fatty acid (FA) composition and mRNA abundance of key candidate genes involved in mammary lipogenesis. Twelve lactating Assaf ewes (on average $63 \mathrm{~d}$ in milk) were randomly assigned to 2 treatments consisting of a total mixed ration based on alfalfa hay and concentrates (50:50), supplemented with 0 (control) or $17 \mathrm{~g}$ of fish oil $/ \mathrm{kg}$ of diet dry matter (FO). Profiles of milk FA and mRNA abundance of candidate genes in biopsied mammary tissue were examined before starting the treatments and after 1 and 4.5 wk on the diets. As expected, FO induced MFD and modified milk FA composition. Compared with the control, reductions in milk fat concentration and yield were not detected on $\mathrm{d}$ 7 , but reached up to 25 and $22 \%$, respectively, on d 30 . However, increases in confirmed or putative antilipogenic FA (trans-10,cis-12 and trans-9,cis-11 18:2, cis-9 16:1, cis-11 18:1, and oxo-FA) were already established on the early stage of the treatment and lasted until the end of the feeding period. These changes were accompanied by decreases in the mRNA abundance of genes encoding lipogenic enzymes. The coordinated nature of the downregulation, which tended to affect most studied metabolic pathways, including FA activation (ACSS1), de novo synthesis (ACACA and FASN), uptake and transport ( $L P L$ and FABP3), desaturation (SCD1), and esterification (AGAPT6), supports the involvement of a central regulator of milk fat synthesis. In this regard, without ruling out the potential contribution of PPARG, our results suggest that SREBF1
\end{abstract}

Received February 10, 2016.

Accepted June 19, 2016.

${ }^{1}$ Corresponding author: pablo.toral@csic.es would have a relevant role in the MFD syndrome in sheep fed FO. Among the other studied transcription factors, the tendency to a downregulation of INSIG1 was associated with that of $S R E B F 1$, whereas no variation was detected for $S C A P$ or THRSP. Fish oil had no significant effects on the transcript abundance of $C D 36$, GPAM, DGAT1, LPIN1, and XDH. Overall, changes in potential antilipogenic FA and mRNA abundance of candidate lipogenic genes support a relationship between them and suggest that FO-induced MFD in dairy ewes would be mediated by transcriptional mechanisms. Key words: fatty acid, gene expression, marine lipid, nutrigenomics, sheep

\section{INTRODUCTION}

Without ruling out the potential involvement of other causative factors, it is widely accepted that the low-milk fat syndrome is mediated by alterations of ruminal fermentation resulting in the formation of specific bioactive fatty acids (FA) that will exert antilipogenic effects in the mammary gland (Bauman and Griinari, 2001; Shingfield et al., 2010). However, the molecular mechanisms by which these FA are able to decrease mammary synthesis of fat remain uncertain (Bauman et al., 2011). Based on studies in dairy cows, the low-milk fat syndrome, commonly referred to as milk fat depression (MFD), has been hypothesized to be caused by alterations in lipogenic gene expression by dietary nutrients (Harvatine and Bauman, 2006; Angulo et al., 2012; Bionaz et al., 2015). The downregulation of the mRNA abundance of key genes involved in milk fat synthesis by trans-10,cis-12 CLA is likely the best-known example of nutrigenomics in this area (Shingfield et al., 2010; Bauman et al., 2011; Hussein et al., 2013).

Nevertheless, information about nutrigenomics and lipid metabolism in small ruminants is not only scarce but also inconsistent (Shingfield et al., 2013). For example, Hussein et al. (2013) reported that trans10,cis-12 CLA-induced MFD in lactating ewes involves the $S R E B F$ family and a coordinated downregulation of genes related to mammary lipid synthesis (e.g., $A C A$ - 
CA, FASN, SCD1, AGPAT6, SREBF1, or INSIG1). In contrast, several studies in dairy sheep (Dervishi et al., 2012; Bichi et al., 2013a; Castro-Carrera et al., 2015) or dairy goats (Bernard et al., 2008; Tsiplakou et al., 2009; Toral et al., 2013) observed a weak relationship between changes in milk FA production and mammary mRNA abundance of key candidate genes and transcription factors involved in lipid metabolism. Yet, Bichi et al. (2013a), who studied that relationship after $54 \mathrm{~d}$ on marine lipids, suggested that transcriptional regulation in dairy ewes might have been established earlier during the feeding period. This speculation was based on the findings of Invernizzi et al. (2010) in mammary tissue from dairy cows fed saturated lipids or soybean oil and fish oil, who observed that transcriptional control mechanisms altering the expression of several lipogenic genes (e.g., PPARG, LPIN1, SREBF1, ACSS1, ACA$C A, F A S N$, or $L P L)$ were affected by d 7 postfeeding, but variations between diets had disappeared on $\mathrm{d} 21$.

This experiment was therefore conducted in dairy ewes to study the effect of dietary supplementation with marine lipids, which is known to induce MFD in this species (Capper et al., 2007; Bichi et al., 2013b; Toral et al., 2016b), on milk fat composition and mRNA abundance of key candidate genes involved in mammary lipogenesis. Based on previous reports (Toral et al., 2010; Hussein et al., 2013), we hypothesized that changes in FA composition and gene expression would be detected early during the feeding period, whereas the milk fat decrease would only be observed later on. To test this hypothesis, transcript and FA profiles were examined before starting the assay and after 1 and 4.5 wk on a control or a fish oil supplemented diet.

\section{MATERIALS AND METHODS}

\section{Animals, Experimental Diets, and Management}

All experimental procedures were approved and completed in accordance with the Spanish Royal Decree 53/2013 for the protection of animals used for experimental purposes. Twelve lactating Assaf ewes $(\mathrm{BW}=77.8 \mathrm{~kg}, \mathrm{SD}=7.81 ; \mathrm{DIM}=63, \mathrm{SD}=7.8$; milk production $=2.5 \mathrm{~kg} / \mathrm{d}, \mathrm{SD}=0.35)$ were housed in individual tie stalls and randomly allocated to 1 of 2 groups $(\mathrm{n}=6)$. They were used to test the effects of 2 dietary treatments consisting of a TMR, based on alfalfa hay (particle size $>4 \mathrm{~cm}$ ) and concentrates (50:50), without lipid supplementation (control) or supplemented with $17 \mathrm{~g}$ of fish oil (Afampes $121 \mathrm{DHA}$; Afamsa, Mos, Spain) $/ \mathrm{kg}$ of diet DM (FO). The ingredients and chemical composition of the experimental diets, which were prepared weekly and included molasses to reduce selection of components, are presented in
Table 1. Formulation and chemical composition of the TMR without lipid supplementation (control) or supplemented with $17 \mathrm{~g}$ of fish oil/ $\mathrm{kg}$ of $\mathrm{DM}(\mathrm{FO})$

\begin{tabular}{|c|c|c|}
\hline \multirow[b]{2}{*}{ Item } & \multicolumn{2}{|c|}{ TMR } \\
\hline & Control & FO \\
\hline \multicolumn{3}{|l|}{ Ingredient, $\mathrm{g} / \mathrm{kg}$ of fresh matter } \\
\hline Dehydrated alfalfa hay & 500 & 493 \\
\hline Whole corn grain & 140 & 138 \\
\hline Whole barley grain & 100 & 99 \\
\hline Soybean meal solvent $440, \mathrm{~g}$ of $\mathrm{CP} / \mathrm{kg}$ & 150 & 148 \\
\hline Sugar beet pulp, pellets & 50 & 49 \\
\hline Molasses, liquid & 40 & 39 \\
\hline Fish oil $^{1}$ & 0 & 15 \\
\hline Mineral supplement $^{2}$ & 18 & 18 \\
\hline Vitamin supplement $^{3}$ & 2 & 2 \\
\hline \multicolumn{3}{|l|}{ Chemical composition, $\mathrm{g} / \mathrm{kg}$ of DM } \\
\hline $\mathrm{OM}$ & 904 & 902 \\
\hline $\mathrm{CP}$ & 187 & 181 \\
\hline $\mathrm{NDF}$ & 251 & 240 \\
\hline $\mathrm{ADF}$ & 155 & 145 \\
\hline 14:0 & 0.60 & 1.16 \\
\hline $16: 0$ & 5.49 & 8.78 \\
\hline cis-9 16:1 & 0.00 & 0.77 \\
\hline $18: 0$ & 1.07 & 2.04 \\
\hline cis-9 18:1 & 4.17 & 7.22 \\
\hline cis-11 18:1 & 0.31 & 0.89 \\
\hline $18: 2 \mathrm{n}-6$ & 12.53 & 12.74 \\
\hline $18: 3 n-3$ & 3.15 & 3.26 \\
\hline $20: 5 n-3$ & 0.00 & 1.08 \\
\hline $22: 5 n-3$ & 0.00 & 0.27 \\
\hline $22: 6 n-3$ & 0.00 & 3.86 \\
\hline Total fatty acids & 28.1 & 43.7 \\
\hline
\end{tabular}

Semi-refined tuna and sardine oil (Afampes 121 DHA; Afamsa, Mos, Spain); contained (g/100 g of total fatty acids): 14:0 (3.1), 16:0 (18.6) cis-9 16:1 (4.2), 17:0 (0.8), 18:0 (5.4), cis-9 18:1 (17.2), cis-11 18:1 (3.2), 18:2n-6 (2.3), 18:3n-3 (0.9), cis-11 20:1 (1.8), 20:5n-3 (5.9), 22:5n-3 (1.5), and 22:6n-3 (21.2).

${ }^{2}$ Declared as containing (g/kg): $\mathrm{CaCO}_{3}$ (556), $\mathrm{Ca}_{2} \mathrm{HPO}_{4}$ (222), and $\mathrm{NaCl}(222)$.

${ }^{3}$ VITAFAC Ovino $0.2 \%$ AC (DSM Nutritional Products S.A., Madrid, Spain). Declared as containing: vitamin A $(4,000,000 \mathrm{IU} / \mathrm{kg})$, vitamin $\mathrm{D}_{3}(1,000,000 \mathrm{IU} / \mathrm{kg})$, vitamin E $(5 \mathrm{~g} / \mathrm{kg})$, iron $(17.5 \mathrm{~g} / \mathrm{kg})$, manganese $(20 \mathrm{~g} / \mathrm{kg})$, cobalt $(50 \mathrm{mg} / \mathrm{kg})$, iodine $(250 \mathrm{mg} / \mathrm{kg})$, zinc $(15 \mathrm{~g} / \mathrm{kg})$, selenium $(100 \mathrm{mg} / \mathrm{kg})$, sepiolite $(100 \mathrm{~g} / \mathrm{kg})$, calcium $(26.2 \mathrm{~g} / \mathrm{kg})$, and magnesium $(6.15 \mathrm{~g} / \mathrm{kg})$.

Table 1. All ewes were fed the control diet during 4 wk of adaptation before the start of the study. The TMR were offered twice daily, at 0930 and $1830 \mathrm{~h}$, to ensure ad libitum intakes. Ewes had continuous access to clean drinking water and were milked at approximately 0900 and $1800 \mathrm{~h}$ in a dedicated $1 \times 10$-stall milking parlor (DeLaval, Madrid, Spain).

\section{Measurements and Sampling Procedures}

Diets. Representative samples of the experimental diets, collected weekly, and the fish oil were stored at $-30^{\circ} \mathrm{C}$ until analysis. Feed intake was measured on $\mathrm{d}$ 0 (pretreatment), 7, and 30 by weighing the amount of DM offered and refused by each ewe. 
Milk. Milk yield was recorded on d 0 (pretreatment), 7 , and 30 , and individual milk samples were collected and composited according to morning and evening milk yield. One aliquot of composite milk was stored at $-30^{\circ} \mathrm{C}$ until milk FA composition analysis, whereas another aliquot was preserved with bronopol (D \& F Control Systems Inc., San Ramon, CA) and stored at $4^{\circ} \mathrm{C}$ until analyzed for fat and CP.

Biopsies. Two weeks before starting the experiment (i.e., the administration of the 2 experimental diets; pretreatment) and on d 8 and 31 on the treatments, mammary tissue samples were biopsied from each ewe. Biopsies were performed with local anesthesia of the area by subcutaneous injection of lidocaine (Anesvet, Laboratorios Ovejero S.A., León, Spain). A 4-cm incision was made at the midpoint section of a halfudder, through the skin and underlying fascia until the mammary capsule was clearly visible. Tissue samples $(\approx 25 \mathrm{mg})$ were then collected using disposable needles (12-gauge $\times 10 \mathrm{~cm}, \mathrm{MN1210}$, Bard Magnum, Bard Biopsy Systems, Tempe, AZ) for Magnum reusable core biopsy instrument (MG1522, Bard Biopsy Systems), immediately frozen in liquid $\mathrm{N}_{2}$, and stored at $-80^{\circ} \mathrm{C}$ until RNA extraction. Briefly (see Toral et al., 2015b for details), the wound was treated with adrenaline, and the incision was closed with suture clips and sprayed with topical antibiotic (oxytetracycline) and a woundhealing product (micronized aluminum powder). Ewes also received injections of antibiotic (amoxicillin and colistin), anti-inflammatory (ketoprofen), and systemic hemostatic drugs (ethamsylate). No incidences of mastitis were detected for any ewe in the study.

\section{Laboratory Analysis}

Diets. Samples were analyzed for DM (ISO, 1999a), ash (ISO, 2002), and CP (ISO, 2009). The NDF and $\mathrm{ADF}$ were determined using an Ankom ${ }^{2000}$ fiber analyzer (Ankom Technology Methods 13 and 12, respectively; Ankom Technology Corp., Macedon, NY); the former was assayed with sodium sulfite and $\alpha$-amylase, and both were expressed with residual ash. Fatty acid methyl esters of lipid in freeze-dried samples of TMR were prepared in a 1-step extraction-transesterification procedure using chloroform (Sukhija and Palmquist, 1988 ) and $2 \%$ (vol/vol) sulfuric acid in methanol (Shingfield et al., 2003), and cis-12 tridecenoate (Larodan, Solna, Sweden) as an internal standard. Methyl esters were separated and quantified using a gas chromatograph (Agilent 7890A GC System, Agilent Technologies Inc., Santa Clara, CA) equipped with a flame-ionization detector and a 100-m fused silica capillary column $(0.25$ $\mathrm{mm}$ i.d., 0.2- $\mu \mathrm{m}$ film thickness; CP-SIL 88, CP7489, Varian Ibérica S.A., Madrid, Spain) and hydrogen as the carrier gas $(207 \mathrm{kPa}, 2.1 \mathrm{~mL} / \mathrm{min})$. The total FAME profile in a $2-\mu \mathrm{L}$ sample volume at a split ratio of $1: 50$ was determined using a temperature gradient program (Shingfield et al., 2003). Peaks were identified based on retention time comparisons with commercially available standard FAME mixtures (Nu-Chek Prep, Elysian, MN; and Sigma-Aldrich, Madrid, Spain).

Milk. Fat and CP concentrations were determined by infrared spectrophotometry (ISO, 1999b) using a MilkoScan FT6000 (Foss, Hillerød, Denmark). Lipid in $1 \mathrm{~mL}$ of milk was extracted using diethylether and hexane (5:4, vol/vol) and transesterified to FAME using freshly prepared methanolic sodium methoxide as a catalyst (Shingfield et al., 2003). The total FAME profile was determined by gas chromatography using the same chromatograph and temperature gradient program applied for the analysis of feeds, but isomers of 18:1 were further resolved in a separate analysis under isothermal conditions at $170^{\circ} \mathrm{C}$ (Shingfield et al., 2003). Peaks were identified based on retention time comparisons with the same FAME mixtures used for the analysis of feeds, other commercially available standards (Nu-Chek Prep, Sigma-Aldrich, and Larodan), cross referencing with chromatograms reported in the literature (Shingfield et al., 2003; Halmemies-BeauchetFilleau et al., 2011), and comparison with reference samples for which the FA composition was determined based on gas chromatography analysis of FAME and GC-MS analysis of corresponding 4,4-dimethyloxazoline derivatives (Bichi et al., 2013b).

Mammary Tissue, RNA Isolation, and Quantitative PCR. Total RNA from the mammary secretory tissue was isolated and purified (PureLink RNA Mini kit, Invitrogen, Carlsbad, CA) as described in Bonnet et al. (2013), with the exception that the tissue was homogenized using a bead beater (Mini-bead Beater-8, BioSpec Products, Bartlesville, OK). The concentration and purity of RNA was determined by spectrophotometry using a Nano-Drop ND-1000 spectrophotometer (Nano-Drop Technologies, Wilmington, $\mathrm{DE}$ ), and RNA integrity by capillary electrophoresis (Agilent 2100 Bioanalyzer, Agilent Technologies Inc.). The average RNA integrity number of the samples was $8.1 \pm 0.46$. For quantitative PCR (qPCR) analysis, cDNA was synthesized using the High Capacity RNA-to-cDNA kit (Applied Biosystems, Foster City, $\mathrm{CA}$ ) and the lack of DNA contamination was verified by a PCR amplification using $A C T B$ primers flanking an intron (Supplemental Table S1; http://dx.doi. org/10.3168/jds.2016-11019). The qPCR was carried out (Bonnet et al., 2013) using a 7500 Real-Time PCR System (Applied Biosystems) and specific primers for the main candidate genes and transcription factors involved in mammary lipogenesis. These genes are de- 
Table 2. Candidate genes studied in the mammary tissue of experimental ewes

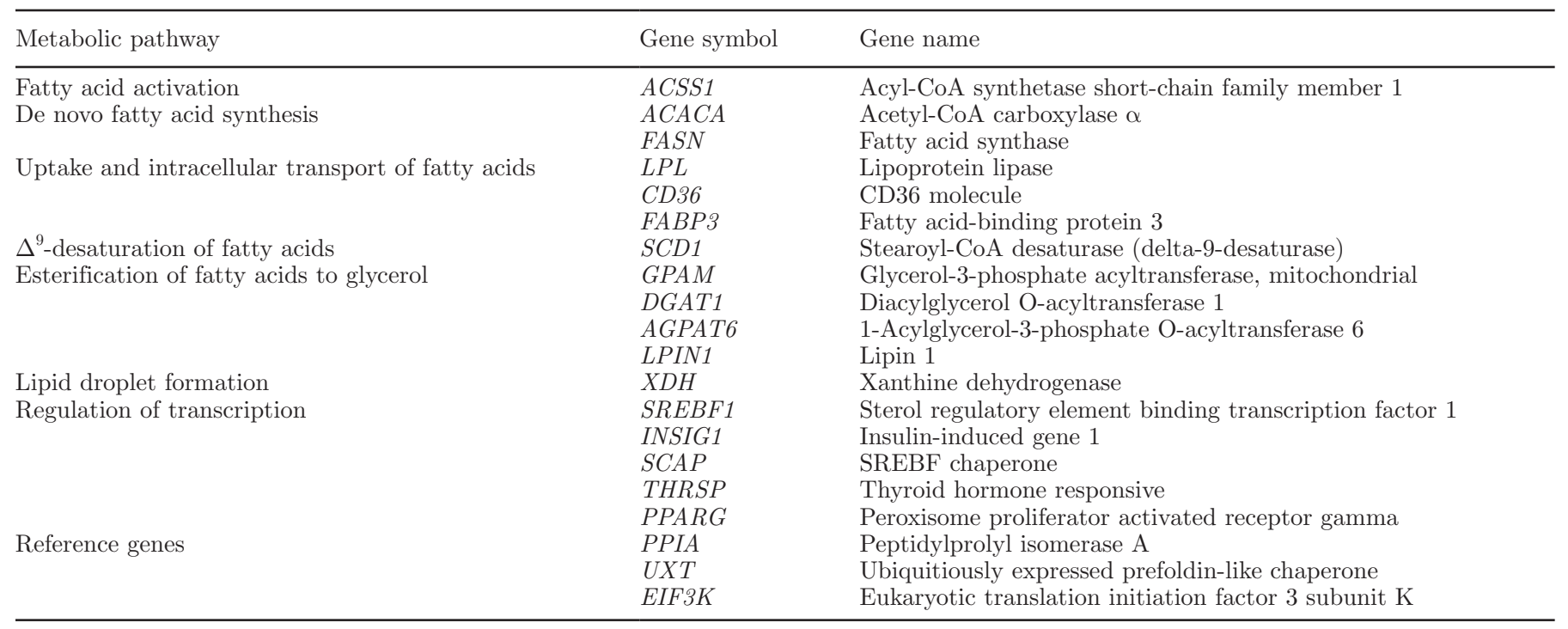

scribed in Table 2 and were selected on the basis of previous works on lipid metabolism in ruminants (e.g., Bernard et al., 2008; Bauman et al., 2011; Ma and Corl, 2012). To account for variations in RNA integrity and quantification and cDNA synthesis, mRNA abundance was normalized using the geometric mean of 3 reference genes (Table 2), which have been identified as suitable internal controls (Bionaz and Loor, 2007; Bonnet et al., 2013) and were confirmed as the most stable genes among those quantified using the geNorm procedure (Vandesompele et al., 2002). The primer sequences and qPCR performance are shown in Supplemental Tables $\mathrm{S} 1$ and S2, respectively (http://dx.doi.org/10.3168/ jds.2016-11019). The abundance of gene transcripts was expressed as the $\log _{2}$ value of mRNA copy number relative to the geometric mean of the 3 reference genes.

\section{Statistical Analysis}

All statistical analyses were performed using the SAS software package (version 9.4, SAS Institute Inc., Cary, NC). After the second biopsies, 2 animals from each group were removed from the assay because they showed a slow recovery. Animal performance, milk FA composition, and mammary mRNA abundances of candidate genes ( $\log _{2}$-transformed values) were analyzed for repeated measures using PROC MIXED. For each variable, the covariance structure (e.g., compound symmetric, first-order autoregressive, heterogeneous first-order autoregressive, first-order antedependence, or unstructured) was selected on the basis of Schwarz's Bayesian information model fit criterion. The statistical model included the fixed effects of diet, sampling time, their interaction, and the pretreatment record (i.e., d 0 for animal performance and milk FA composition and d -13 for gene mRNA abundances) as a covariate. When the $P$-value for the interaction of diet $\times$ sampling time was $<0.10$, a previously defined orthogonal contrast (FO-d 30 vs. control-d $7+$ control-d $30+$ FO-d 7 for animal performance and milk FA composition data, and FO-d 31 vs. control-d $8+$ control-d $31+$ FO-d 8 for mammary mRNA abundance data) was used to test that the effect of FO supplementation was not detected early (d 7-8) but late (d 30-31) during the feeding period. Differences were declared significant at $P<0.05$ and considered a trend toward significance at $P<0.10$, and least squares means (adjusted for the covariance) are reported throughout.

\section{RESULTS}

\section{Animal Performance and Milk Composition}

Fish oil supplementation had no effect on DMI and milk yield, but significantly modified milk composition (Table 3). Compared with the control, reductions in milk fat concentration and yield were not detected on $\mathrm{d}$ 7 , but reached up to 25 and $22 \%$, respectively, on d 30 . The milk protein content also tended to be decreased by FO, but to a lower extent $(-6 \%)$ and on both sampling days. Time exerted a negative effect on milk yield.

\section{Milk Fatty Acid Composition}

Addition of fish oil to the diet had a marked influence on milk FA composition (Table 4 and Supplementary 
Table S3; http://dx.doi.org/10.3168/jds.2016-11019). Variations in relative proportions of FA derived from mammary uptake were generally more relevant than those observed in de novo synthesized FA, and most changes were already detected on $\mathrm{d} 7$ and comparable on both sampling days. For example, concentrations of the antilipogenic trans-10,cis-12 CLA and other trans 18:2 intermediate metabolites, such as trans-9,cis-12 and trans-11,cis-15 18:2, or cis-9,trans-11, trans11,cis-13, and trans,trans CLA, were increased several times compared with the control. These increases were similar on $\mathrm{d} 7$ and 30 . On the contrary, the large increment in trans-9,cis-11 CLA was greater at the end of the trial, coincident with a rise in trans-10 18:1 and a less pronounced increase in trans-11 18:1.

Notable variations in milk long-chain FA also included reductions in the major $\mathrm{C} 18 \mathrm{FA}$, namely 18:0 and cis-9 18:1, which averaged 69 and $41 \%$, respectively, as well as an increase in oxo-FA, which tended to be greater on d 30, and in cis-11 18:1. Similarly, the proportions of very long-chain n-3 PUFA (i.e., 20:5n-3, 22:5n-3, and 22:6n-3) were augmented with this treatment, whereas the milk concentration of major PUFA in the control (namely, 18:2n-6 and 18:3n-3) was negatively affected by oil supplementation. The percentage of some shortand medium-chain FA in milk was also modified by the FO diet, with decreases in 4:0, cis-9 12:1, 14:0, and cis-9 14:1, and increases in 8:0, cis-9 16:1 and trans-9 $16: 1$ that were comparable in both sampling days. However, the concentration of milk 10:0 was increased in the early stage of the treatment (d 7), and that of 6:0 tended to be higher at the end point (d 30).

On a molar basis, FA with less than 16 carbons accounted for $43 \%$ of the reduction in milk fat yield with FO on d 30, and those with 18 or more carbon atoms for $27 \%$, whereas the other $30 \%$ was explained by C16 FA (data not shown in tables).

\section{mRNA Abundance of Candidate Genes}

As shown in Table 5, the mRNA abundance of most candidate genes was affected by either diet or time. The lipogenic genes ACACA, ACSS1, and AGPAT6, and the transcription factor $S R E B F 1$ were downregulated in the mammary tissue of ewes fed FO. Also, the abundance of FABP3, LPL, SCD1, and INSIG1 transcripts tended to be reduced by marine lipid supplementation. All these changes in gene expression were already identified on d 8 and remained stable afterward, whereas those of FASN were only detected on d 31 . With regard to the effect of time on candidate gene expression, greater mRNA abundances of PPARG1 and THRSP were found on d 31 compared with d 8, and the opposite behavior was observed for ACSS1, DGAT1, GPAM, LPIN1, SCAP, and SREBF1.

\section{DISCUSSION}

Dietary supplementation of dairy ewes with marine lipids is known to modulate milk FA composition toward a potentially healthier profile for consumers (Capper et al., 2007; Bichi et al., 2013b; Toral et al., 2016b). However, it induces MFD, which has a negative effect on ovine cheese making and hampers the implementation of this feeding strategy. Because the causative factors and mechanisms involved in this syndrome are still uncertain, as in dairy cows, MFD remains an active area of research (Hussein et al., 2013; Bionaz et al., 2015; Toral et al., 2015a).

In the present study, fish oil was used as a mean of experimentally decreasing milk fat concentration and yield in sheep, based on earlier reports indicating that this species is not prone to develop MFD with plant oils (Mele et al., 2006; Pulina et al., 2006; Castro-Carrera et al., 2015). This is probably the first but not the only

Table 3. Intake, and milk yield and composition in lactating ewes fed a TMR without lipid supplementation (control) or supplemented with $17 \mathrm{~g}$ of fish oil $/ \mathrm{kg}$ of DM (FO)

\begin{tabular}{|c|c|c|c|c|c|c|c|c|c|c|c|}
\hline Item & \multicolumn{2}{|c|}{ Pretreatment $^{1}$} & \multicolumn{2}{|c|}{ Day 7} & \multicolumn{2}{|c|}{ Day 30} & $\mathrm{SED}^{2}$ & \multicolumn{3}{|c|}{$P$-value ${ }^{3}$} & Contrast $^{4}$ \\
\hline DMI, g/d & 3,375 & 3,465 & 3,390 & 3,281 & 3,308 & 3,107 & 198.3 & 0.221 & 0.313 & 0.710 & \\
\hline Fat, $\%$ & 5.92 & 5.77 & 5.89 & 5.90 & 5.98 & 4.51 & 0.054 & 0.062 & 0.065 & 0.043 & 0.005 \\
\hline Fat, $\mathrm{g} / \mathrm{d}$ & 150.5 & 146.9 & 151.0 & 159.0 & 125.4 & 97.5 & 11.33 & 0.156 & 0.002 & 0.041 & $<0.001$ \\
\hline Protein, \% & 5.26 & 5.21 & 5.26 & 5.00 & 5.39 & 5.08 & 0.158 & 0.065 & 0.110 & 0.614 & \\
\hline
\end{tabular}

\footnotetext{
${ }^{1}$ Data collected on d 0 .

${ }^{2} \mathrm{SED}=$ standard error of the difference.

${ }^{3}$ Probability of significant effects due to diet (D), time $(\mathrm{T})$, and their interaction $(\mathrm{D} \times \mathrm{T})$.

${ }^{4}$ Probability of the orthogonal contrast: FO-d 30 vs. control-d $7+$ control-d $30+$ FO-d 7.
} 
difference when comparing this syndrome in ovine and bovine. As expected, feeding FO caused MFD, with a reduction in milk fat content $(25 \%$ on $\mathrm{d} 30)$ that was within the range observed in lactating sheep consuming marine lipids (17-31\%; Capper et al., 2007; Toral et al., 2010; Bichi et al., 2013b).

The MFD syndrome has been defined in dairy cows as a reduction in milk fat synthesis with no change in the yield of milk and other components (Bauman et al., 2011). In dairy ewes, however, MFD is often accompanied by small decreases in milk protein concentration (approximately 5-7\%; Toral et al., 2010, 2016b), which is consistent with our results. Mechanisms involved in milk protein depression might be speculated to be independent from those underlying the inhibition in lipogenesis, because reductions in protein content also occur in the absence of changes in milk fat synthesis when sheep receive lipid supplements (e.g., Mele et al., 2006; Pulina et al., 2006). This is in agreement with our observations on $\mathrm{d} 7$, when MFD had not been detected yet.

Another difference between dairy cows and sheep is that several nutritional assays in cows have shown a relationship between marine lipid-induced MFD and changes in mammary gene expression (e.g., Ahnadi et al., 2002; Harvatine and Bauman, 2006; Angulo et al., 2012), whereas this link is not so clear in ewes. For instance, Bichi et al. (2013a) could not detect any

Table 4. Milk fatty acid composition in lactating ewes fed a TMR without lipid supplementation (control) or supplemented with 17 g of fish oil/kg of DM (FO; data on additional fatty acids are reported in Supplemental Table S3; http://dx.doi.org/10.3168/jds.2016-11019)

\begin{tabular}{|c|c|c|c|c|c|c|c|c|c|c|c|}
\hline \multirow{2}{*}{$\begin{array}{l}\text { Fatty acid, g/100 g } \\
\text { of total fatty acids }\end{array}$} & \multicolumn{2}{|c|}{ Pretreatment $^{1}$} & \multicolumn{2}{|c|}{ Day 7} & \multicolumn{2}{|c|}{ Day 30} & \multirow[b]{2}{*}{$\mathrm{SED}^{2}$} & \multicolumn{3}{|c|}{$P$-value ${ }^{3}$} & \multirow[b]{2}{*}{ Contrast $^{4}$} \\
\hline & Control & $\mathrm{FO}$ & Control & $\mathrm{FO}$ & Control & $\mathrm{FO}$ & & $\mathrm{D}$ & $\mathrm{T}$ & $\mathrm{D} \times \mathrm{T}$ & \\
\hline 4:0 & 3.00 & 2.90 & 2.80 & 2.50 & 2.85 & 2.72 & 0.111 & 0.034 & 0.046 & 0.175 & \\
\hline $6: 0$ & 2.73 & 2.68 & 2.65 & 2.81 & 2.69 & 2.95 & 0.130 & 0.138 & 0.011 & 0.080 & 0.022 \\
\hline 8:0 & 2.97 & 3.00 & 3.02 & 3.54 & 3.03 & 3.48 & 0.214 & 0.039 & 0.626 & 0.536 & \\
\hline $10: 0$ & 10.58 & 11.22 & 10.96 & 12.37 & 10.89 & 11.56 & 0.601 & 0.108 & 0.010 & 0.020 & 0.714 \\
\hline cis-9 10:1 & 0.28 & 0.25 & 0.29 & 0.27 & 0.32 & 0.32 & 0.019 & 0.558 & 0.004 & 0.666 & \\
\hline $12: 0$ & 6.65 & 7.25 & 7.21 & 7.34 & 6.84 & 6.72 & 0.400 & 0.996 & 0.002 & 0.247 & \\
\hline cis-9 12:1 & 0.11 & 0.11 & 0.13 & 0.11 & 0.14 & 0.10 & 0.012 & 0.039 & 0.677 & 0.638 & \\
\hline $14: 0$ & 12.69 & 12.95 & 13.01 & 11.72 & 13.01 & 11.77 & 0.411 & 0.001 & 0.936 & 0.927 & \\
\hline cis-9 14:1 & 0.21 & 0.20 & 0.22 & 0.17 & 0.24 & 0.20 & 0.025 & 0.019 & 0.132 & 0.707 & \\
\hline $16: 0$ & 27.09 & 25.72 & 26.72 & 24.66 & 25.78 & 25.16 & 1.274 & 0.182 & 0.760 & 0.338 & \\
\hline cis-9 16:1 & 0.70 & 0.61 & 0.74 & 0.90 & 0.79 & 1.06 & 0.097 & 0.028 & 0.056 & 0.233 & \\
\hline trans-9 16:1 & 0.08 & 0.07 & 0.08 & 0.37 & 0.08 & 0.26 & 0.082 & 0.005 & 0.298 & 0.247 & \\
\hline $18: 0$ & 6.43 & 6.93 & 6.00 & 2.12 & 6.05 & 1.65 & 0.327 & $<0.001$ & 0.443 & 0.242 & \\
\hline cis-9 $18: 1^{5}$ & 12.32 & 11.54 & 11.18 & 7.39 & 12.07 & 6.32 & 0.677 & $<0.001$ & 0.839 & 0.058 & $<0.001$ \\
\hline cis-11 18:1 & 0.79 & 0.76 & 0.73 & 0.98 & 0.78 & 1.06 & 0.085 & 0.001 & 0.265 & 0.745 & \\
\hline trans-10 18:1 & 0.19 & 0.24 & 0.36 & 0.62 & 0.38 & 2.78 & 0.675 & 0.031 & 0.004 & 0.005 & $<0.001$ \\
\hline trans-11 18:1 & 1.08 & 0.97 & 1.13 & 5.65 & 1.19 & 4.40 & 0.510 & $<0.001$ & 0.053 & 0.037 & $<0.001$ \\
\hline $10-+13$-oxo- $18: 0$ & $<0.01$ & $<0.01$ & $<0.01$ & 0.23 & $<0.01$ & 0.37 & 0.505 & $<0.001$ & 0.057 & 0.073 & $<0.001$ \\
\hline cis-9,cis-12 18:2 & 2.46 & 2.50 & 2.39 & 2.02 & 2.41 & 1.92 & 0.137 & 0.004 & 0.512 & 0.340 & \\
\hline cis-9,trans-12 18:2 & 0.07 & 0.06 & 0.07 & 0.08 & 0.07 & 0.09 & 0.009 & 0.079 & 0.308 & 0.073 & 0.026 \\
\hline cis-9,trans-13 18:2 & 0.17 & 0.17 & 0.17 & 0.24 & 0.18 & 0.26 & 0.025 & 0.002 & 0.348 & 0.768 & \\
\hline cis-9,trans-14 18:2 & 0.07 & 0.08 & 0.07 & 0.05 & 0.07 & 0.04 & 0.008 & 0.010 & 0.232 & 0.663 & \\
\hline trans-9,cis-12 18:2 & 0.02 & 0.02 & 0.03 & 0.07 & 0.03 & 0.08 & 0.009 & $<0.001$ & 0.418 & 0.304 & \\
\hline trans-11,cis-15 18:2 & 0.07 & 0.07 & 0.08 & 0.36 & 0.07 & 0.38 & 0.054 & $<0.001$ & 0.731 & 0.615 & \\
\hline 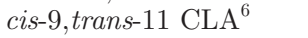 & 0.54 & 0.44 & 0.51 & 2.28 & 0.53 & 2.28 & 0.307 & $<0.001$ & 0.938 & 0.920 & \\
\hline trans-9,cis-11 CLA & 0.03 & 0.03 & 0.03 & 0.12 & 0.04 & 0.16 & 0.021 & 0.001 & 0.008 & 0.033 & $<0.001$ \\
\hline trans-10,cis-12 CLA & $<0.01$ & $<0.01$ & $<0.01$ & 0.02 & $<0.01$ & 0.02 & 0.004 & $<0.001$ & 0.688 & 0.647 & \\
\hline trans-11,cis-13 CLA & 0.01 & 0.02 & 0.01 & 0.04 & 0.01 & 0.03 & 0.007 & 0.001 & 0.347 & 0.266 & \\
\hline Other trans,trans $\mathrm{CLA}^{7}$ & 0.03 & 0.03 & 0.03 & 0.04 & 0.03 & 0.04 & 0.007 & 0.013 & 0.803 & 0.719 & \\
\hline $18: 3 n-3$ & 0.62 & 0.64 & 0.60 & 0.53 & 0.58 & 0.46 & 0.047 & 0.056 & 0.027 & 0.238 & \\
\hline $20: 5 n-3$ & 0.06 & 0.05 & 0.07 & 0.28 & 0.07 & 0.35 & 0.041 & $<0.001$ & 0.203 & 0.239 & \\
\hline$\Sigma$ unsaturated C20 & 0.33 & 0.34 & 0.33 & 0.97 & 0.40 & 0.99 & 0.099 & $<0.001$ & 0.562 & 0.729 & \\
\hline $22: 5 n-3$ & 0.10 & 0.10 & 0.10 & 0.35 & 0.10 & 0.35 & 0.041 & $<0.001$ & 0.863 & 0.956 & \\
\hline $22: 6 n-3$ & 0.05 & 0.05 & 0.04 & 0.78 & 0.03 & 0.99 & 0.107 & $<0.001$ & 0.213 & 0.188 & \\
\hline$\Sigma$ unsaturated C22 & 0.21 & 0.21 & 0.18 & 1.39 & 0.21 & 1.60 & 0.165 & $<0.001$ & 0.320 & 0.478 & \\
\hline
\end{tabular}

${ }^{1}$ Data collected on d 0.

${ }^{2} \mathrm{SED}=$ standard error of the difference.

${ }^{3}$ Probability of significant effects due to diet (D), time $(\mathrm{T})$, and their interaction $(\mathrm{D} \times \mathrm{T})$.

${ }^{4}$ Probability of the orthogonal contrast: FO-d 30 vs. control-d $7+$ control-d $30+$ FO-d 7 .

${ }^{5}$ Contains trans-13, -14, and $-1518: 1$ and cis-10 18:1 as minor components.

${ }^{6}$ Contains trans-8, cis-10 and trans-7,cis-9 CLA as minor components.

${ }^{7}$ Sum of trans-8,trans-10, trans-9,trans-11, trans-10,trans-12, and trans-11,trans-13 CLA. 
significant relationship between the MFD observed in dairy sheep after $54 \mathrm{~d}$ of diet supplementation with microalgae and the mRNA abundance of the studied lipogenic genes. However, concurring with our results and based on findings by Invernizzi et al. (2010), the authors suggested that transcriptional regulation mechanisms could be established early during the feeding period.

In line with this, we observed higher contents of trans-10,cis-12 and trans-9,cis-11 18:2, 2 CLA isomers with confirmed or putative, respectively, antilipogenic properties after only $7 \mathrm{~d}$ on FO. Yet, these increments were lower than those reported to affect milk fat synthesis when administered separately (Perfield et al., 2007; Shingfield et al., 2010; Hussein et al., 2013). This contributes to its actual involvement in FO-induced MFD remaining uncertain and supports that other less well-known inhibitor FA might play a relevant role in the low- milk fat syndrome. In this regard, our results agree with recent reports that suggest a potential influence of cis-9 16:1, cis-11 18:1, and oxo-FA (Kairenius et al., 2015; Toral et al., 2015a, 2016b). Another FA being putatively involved in MFD (Alves and Bessa, 2014; Kairenius et al., 2015) is trans-10,cis-15 18:2. Under our chromatographic conditions, this intermediate probably coelutes with trans-11,cis-15 18:2 (Kairenius et al., 2015), the unresolved peak showing noticeable increases with FO.
Increments in these potentially antilipogenic FA were observed on $\mathrm{d} 7$ and lasted until the end of the experiment. However, the higher concentration of trans-10 18:1 (an intermediate FA with yet-equivocal effects on lipogenesis; Kadegowda et al., 2009; Shingfield et al., 2010) only on d 30 is an exception to the general trend in the temporal pattern of milk FA responses. All these changes were inversely related to variations in the mRNA abundance of genes encoding key lipogenic enzymes, which supports a relationship between them (Gervais et al., 2009; Kadegowda et al., 2009; Hussein et al., 2013) and suggests that FO-induced MFD in dairy ewes would be mediated by downregulation of lipogenic genes. This mechanism, previously observed in other dairy ruminants (Shingfield et al., 2010; Bauman et al., 2011; Bionaz et al., 2015), would have tended to affect most studied metabolic pathways, including FA activation (ACSS1), de novo synthesis (ACACA and FASN), uptake and transport ( $L P L$ and FABP3), desaturation (SCD1), and esterification ( $A G A P T 6)$.

The enzyme encoded by $A C A C A$ has been traditionally considered as responsible for the rate-limiting step in de novo lipogenesis (Bauman and Davis, 1974), but simultaneous decreases in the transcript abundance of this gene and FASN are common features of MFD (e.g., Ahnadi et al., 2002; Peterson et al., 2003; Hussein et al., 2013). Despite both genes would share common regulatory mechanisms (Bernard et al., 2008), reduc-

Table 5. mRNA relative abundance ( $\log _{2}$ transformed data) of candidate genes in mammary tissue of lactating ewes fed a TMR without lipid supplementation (control) or supplemented with $17 \mathrm{~g}$ of fish oil $/ \mathrm{kg}$ of DM (FO)

\begin{tabular}{|c|c|c|c|c|c|c|c|c|c|c|c|}
\hline Item & \multicolumn{2}{|c|}{ Pretreatment $^{1}$} & \multicolumn{2}{|c|}{ Day 8} & \multicolumn{2}{|c|}{ Day 31} & $\mathrm{SED}^{2}$ & \multicolumn{3}{|c|}{$P$-value ${ }^{3}$} & Contrast $^{4}$ \\
\hline$A C A C A$ & 7.09 & 7.22 & 7.26 & 6.61 & 6.95 & 6.25 & 0.385 & 0.030 & 0.175 & 0.910 & \\
\hline$A C S S 1$ & 7.72 & 7.80 & 7.77 & 7.30 & 7.61 & 6.54 & 0.228 & 0.015 & 0.031 & 0.101 & \\
\hline AGPAT6 & 6.91 & 7.52 & 7.50 & 6.96 & 7.53 & 6.54 & 0.266 & 0.004 & 0.274 & 0.211 & \\
\hline CD36 & 7.41 & 7.45 & 7.19 & 7.34 & 7.13 & 7.55 & 0.289 & 0.171 & 0.712 & 0.471 & \\
\hline$F A S N$ & 7.93 & 8.34 & 8.58 & 8.26 & 9.32 & 7.83 & 0.442 & 0.060 & 0.230 & 0.004 & 0.002 \\
\hline GPAM & 6.88 & 7.08 & 6.64 & 6.87 & 6.18 & 6.50 & 0.310 & 0.106 & 0.068 & 0.829 & \\
\hline LPIN1 & 6.11 & 7.05 & 7.32 & 6.56 & 6.73 & 6.13 & 0.588 & 0.178 & 0.095 & 0.776 & \\
\hline$L P L$ & 6.92 & 7.10 & 7.31 & 6.81 & 7.08 & 6.51 & 0.304 & 0.054 & 0.116 & 0.803 & \\
\hline$S C D 1$ & 7.17 & 7.02 & 7.40 & 6.97 & 7.53 & 6.69 & 0.326 & 0.054 & 0.549 & 0.138 & \\
\hline$X D H$ & 7.42 & 7.36 & 7.14 & 7.20 & 6.99 & 7.48 & 0.310 & 0.254 & 0.718 & 0.257 & \\
\hline \multicolumn{12}{|c|}{ Transcription factor } \\
\hline
\end{tabular}

${ }^{1}$ Data collected on $\mathrm{d}-13$.

${ }^{2} \mathrm{SED}=$ standard error of the difference.

${ }^{3}$ Probability of significant effect due to diet $(\mathrm{D})$, time $(\mathrm{T})$, and their interaction $(\mathrm{D} \times \mathrm{T})$.

${ }^{4}$ Probability of the orthogonal contrast: FO-d 31 vs. control-d $8+$ control-d $31+$ FO-d 8. 
tions in FASN mRNA abundance were not observed on the early stage of the treatment.

De novo FA synthesis might have also been limited by the lower mRNA abundance of ACSS1, indirectly involved in this metabolic pathway through acetate activation. Although the available information on this gene in lactating ruminants is scant and inconsistent (Mach et al., 2011; Hussein et al., 2013), our results suggest its implication in fish oil-induced MFD in dairy ewes.

Among the candidate genes codifying for enzymes responsible for FA uptake, $L P L$ has received a great deal of attention. Available data suggest that, under feeding conditions increasing milk long-chain FA yield (e.g., the addition of plant oils to the diet of small ruminants; Bernard et al., 2008; Castro-Carrera et al., 2015), LPL transcript abundance would not be limiting. However, downregulation of this lipogenic gene has been consistently associated with decreases in milk fat synthesis (Harvatine and Bauman, 2006; Angulo et al., 2012; Hussein et al., 2013), which agrees with our results and supports a role in ovine MFD.

Little and erratic information exists about other genes potentially involved in mammary FA uptake and transport in ruminants, such as CD 36 or FABP3. The stability of $C D 36$ transcript abundance observed in the FO treatment as well as in a variety of other feeding conditions (Invernizzi et al., 2010; Hussein et al., 2013; Castro-Carrera et al., 2015) might reflect a low relevance in the transcriptional mechanisms mediating diet-induced changes in lipogenesis. On the other hand, and despite the co-expression of CD36 and FABP3 in the bovine mammary gland (Spitsberg et al., 1995), we detected a tendency for lower mRNA abundance of FABP3 with $\mathrm{FO}$, which may indicate a possible involvement in marine lipid-induced MFD in ewes. This contrasts with the increase reported by Invernizzi et al. (2010) in cows suffering MFD caused by the consumption of FO and soybean oil, and also with the lack of variation in ovine CLA-induced MFD (Hussein et al., 2013).

Following the pathways of milk fat synthesis in the mammary epithelial cell, before the synthesis of milk triacylglycerols, some FA can be subjected to the action of $\Delta^{9}$-desaturase, an enzyme that deserves particular attention due to its key role in milk fat composition (Bernard et al., 2013; Toral et al., 2015b). The nutritional regulation of $S C D 1$ gene expression involves complex interactions between dietary factors and regulatory events that have not been well characterized yet (Bernard et al., 2013). Still, consistent with our results, several studies have shown a downregulation of SCD1 during MFD induced by marine and plant lipid supple- mentation (Ahnadi et al., 2002; Peterson et al., 2003; Angulo et al., 2012) or CLA administration (Baumgard et al., 2002; Gervais et al., 2009), the latter not only in cows but also in dairy ewes (Hussein et al., 2013). Increases in 20:5n-3 and trans-10,cis-12 CLA, which were observed from the early stage of FO treatment, might have been involved in this inhibition (Kadegowda et al., 2009; Bernard et al., 2013).

Due to the diet-induced differences in the availability of cis-9-containing FA and substrates for mammary $\Delta^{9}$-desaturation, it was not possible to associate the tendency to a downregulation of $S C D 1$ with systematic reductions in its product milk concentrations. However, the inhibition might have contributed to a further decline in the already low cis-9 18:1 milk content derived from the shortage of 18:0 of ruminal origin (Shingfield et al., 2003; Toral et al., 2016b). Decreases in these FA have been linked to altered milk fat fluidity and tentatively to the negative effect of marine lipids on mammary lipogenesis (Gama et al., 2008; Shingfield et al., 2010; Bichi et al., 2013b), although some recent results in dairy ewes (Toral et al., 2016b) question its relevance. In any event, it is probably worth mentioning that Bionaz and Loor (2008) speculated that FABP3 would provide 18:0 to the SCD, which would worsen the situation in our study.

The last steps of milk fat synthesis include esterification of FA to glycerol and secretion of milk fat globules. Among the studied candidate genes (i.e., GPAM, AGPAT, DGAT1, LPIN1, and XDH), the lack of variation in DGAT1 transcript abundance during MFD (Invernizzi et al., 2010; Bichi et al., 2013a; Hussein et al., 2013) agrees with our findings and is probably explained by its known posttranscriptional regulation (Bernard et al., 2008). Conversely, the reduction in $A G$ PAT6 mRNA abundance with FO, in line with previous reports (Baumgard et al., 2002; Peterson et al., 2003; Hussein et al., 2013), would suggest a greater relevance of transcriptional regulating mechanisms. Based on our results and on inconsistent changes detected in response to diet-induced MFD (Peterson et al., 2003; Invernizzi et al., 2010; Hussein et al., 2013), this link appears less clear for GPAM, LPIN1, and XDH. Reasons for the specific downregulation of AGPAT6 in ewes fed FO are not clear, but its greater affinity for short- and medium-chain SFA (Bernard et al., 2008) leaves room for speculation about a relationship with the inhibition of de novo lipogenesis.

Overall, the coordinated nature in all these lipogenic gene changes support the involvement of a central regulator of milk fat synthesis (Bernard et al., 2008; Shingfield et al., 2010; Bauman et al., 2011). The SREBF1 and PPARG transcription factors seem to play a promi- 
nent nutrigenomic role through different mechanisms (Bionaz et al., 2015). Thus, PPARG-mediated effects in gene expression do not necessarily involve variations in its mRNA abundance (Kadegowda et al., 2009; Shi et al., 2013), whereas downregulation of SREBF1 is frequently detected during MFD induced by CLA (Gervais et al., 2009; Hussein et al., 2013) or marine lipid supplementation (Harvatine and Bauman, 2006; Invernizzi et al., 2010; Angulo et al., 2012), as observed in our study. Furthermore, there may be complex interactions between them: PPARG could partly control the expression of $S R E B F 1$, which in turn could affect the activity of PPARG by increasing the production of its natural agonists (Bionaz et al., 2015).

Other transcription factors, such as INSIG1 and $S C A P$, are known to be involved in SREBF1 activation to its mature form (the nuclear SREBP1; Sakai et al., 1998; Yang et al., 2002). So far, no clear association between lipid supplementation and changes in $S C A P$ transcript abundance has been demonstrated, in contrast to diet-induced changes in both $I N S I G$ and SREBF1 mRNA abundances during MFD (Harvatine and Bauman, 2006; Mach et al., 2011; Hussein et al., 2013), which concurs with our observations. Reduced SREBF1 transcript abundance in ewes fed FO may be indicative of an inhibition of SREBP1 signaling pathway and of its target genes (Bernard et al., 2008; Ma and Corl, 2012), which could contribute to explain the negative effects of FO on the expression of a large number of our candidate genes, including $A C A C A, F A S N$, $L P L, F A B P 3$, and SCD1.

Concerning THRSP, although there is evidence indicating that this gene acts as a relevant transcriptional regulator in the mammary responses to antilipogenic FA in bovine (Bauman et al., 2011), neither our results nor the little available information in dairy ewes (Bichi et al., 2013a; Hussein et al., 2013) allow confirmation of a similar role in this species. Further research is necessary to elucidate whether observed differences are attributable to interspecies features in the transcriptional regulation of mammary lipogenic genes or in the ruminal metabolism of PUFA (Shingfield et al., 2010; Toral et al., 2016a).

Finally, it is probably worth mentioning that our results do not allow us to conclude a causative relationship between downregulation and lower milk fat synthesis. In fact, some of the enzymes encoded by the candidate genes that we studied might be no longer necessary during MFD, or not as much, and therefore their inhibition might be a consequence of rather than a cause for the low-milk fat syndrome. This would also merit further investigation.

\section{CONCLUSIONS}

Reductions in milk fat concentration and yield in dairy ewes consuming $1.7 \% \mathrm{DM}$ of fish oil were not detected on d 7 but reached up to 25 and $22 \%$, respectively, after $30 \mathrm{~d}$ on the diet. However, increases in potentially antilipogenic FA in milk already appeared on the early stage of treatment and lasted until the end of the feeding period. These increments were accompanied by decreases in the mRNA abundance of candidate genes encoding key lipogenic enzymes, which supports a relationship between them and suggests that FO-induced milk fat depression in dairy ewes would be mediated by transcriptional mechanisms. The coordinated nature of the downregulation, which tended to affect most studied metabolic pathways, including FA activation (ACSS1), de novo synthesis ( $A C A C A$ and $F A S N$ ), uptake and transport ( $L P L$ and $F A B P 3)$, desaturation (SCD1), and esterification (AGAPT6), suggests the involvement of a central regulator of milk fat synthesis. Without ruling out the potential contribution of PPARG, our results suggest that the SREBF1 transcription factor might play a relevant role in the MFD syndrome in lactating sheep fed FO.

\section{ACKNOWLEDGMENTS}

This work was supported by the Council of Castile and Leon (CSI023U13) and the Spanish Ministry of Economy and Competitiveness (MINECO; AGL201454587, co-funded by the European Regional Development Fund). D. Carreño and P. G. Toral benefitted from an FPI predoctoral grant and a Juan de la Cierva research contract, respectively, from the MINECO. The authors thank A. González-Mendoza from the Instituto de Ganadería de Montaña (Spain) for his help in the field work and laboratory analysis. Special gratitude is extended to Y. Chilliard, L. Bernard, C. Leroux (INRA, Clermont-Ferrand, France), and J. J. Arranz (University of León, Spain), and also to L. Barrios (Biostatistics Department, CSIC; Madrid, Spain) for helpful assistance with nutrigenomic techniques and statistical analysis, respectively.

\section{REFERENCES}

Ahnadi, C. E., N. Beswick, L. Delbecchi, J. J. Kennelly, and P. Lacasse. 2002. Addition of fish oil to diets for dairy cows. II. Effects on milk fat and gene expression of mammary lipogenic enzymes. J. Dairy Res. 69:521-531.

Alves, S. P., and R. J. B. Bessa. 2014. The trans-10,cis-15 18:2: A missing intermediate of trans-10 shifted rumen biohydrogenation pathway? Lipids 49:527-541. 
Angulo, J., L. Mahecha, K. Nuernberg, G. Nuernberg, D. Dannenberger, M. Olivera, M. Boutinaud, C. Leroux, E. Albrecht, and L. Bernard. 2012. Effects of polyunsaturated fatty acids from plant oils and algae on milk fat yield and composition are associated with mammary lipogenic and SREBF1 gene expression. Animal 6:1961-1972.

Bauman, D. E., and C. L. Davis. 1974. Biosynthesis of milk fat. Pages 31-75 in Lactation: A Comprehensive Treatise. Vol. 2. B. L. Larson and V. R. Smith, ed. Academic Press, New York, NY.

Bauman, D. E., and J. M. Griinari. 2001. Regulation and nutritional manipulation of milk fat: Low-fat milk syndrome. Livest. Prod. Sci. 70:15-29.

Bauman, D. E., K. J. Harvatine, and A. L. Lock. 2011. Nutrigenomics, rumen-derived bioactive fatty acids, and the regulation of milk fat synthesis. Annu. Rev. Nutr. 31:299-319.

Baumgard, L. H., E. Matitashvili, B. A. Corl, D. A. Dwyer, and D. E. Bauman. 2002. Trans-10, cis-12 conjugated linoleic acid decreases lipogenic rates and expression of genes involved in milk lipid synthesis in dairy cows. J. Dairy Sci. 85:2155-2163.

Bernard, L., C. Leroux, and Y. Chilliard. 2008. Expression and nutritional regulation of lipogenic genes in the ruminant lactating mammary gland. Adv. Exp. Med. Biol. 606:67-108.

Bernard, L., C. Leroux, and Y. Chilliard. 2013. Expression and nutritional regulation of stearoyl-CoA desaturase genes in the ruminant mammary gland: Relationship with milk fatty acid composition. Pages 161-193 in Stearoyl-CoA Desaturase Genes in Lipid Metabolism. J. M. Ntambi, ed. Springer Science+Business Media, New York, NY.

Bichi, E., P. Frutos, P. G. Toral, D. Keisler, G. Hervás, and J. J. Loor 2013a. Dietary marine algae and its influence on tissue gene network expression during milk fat depression in dairy ewes. Anim. Feed Sci. Technol. 186:36-44.

Bichi, E., G. Hervás, P. G. Toral, J. J. Loor, and P. Frutos. 2013b. Milk fat depression induced by dietary marine algae in dairy ewes: Persistency of milk fatty acid composition and animal performance responses. J. Dairy Sci. 96:524-532.

Bionaz, M., and J. J. Loor. 2007. Identification of reference genes for quantitative real-time PCR in the bovine mammary gland during the lactation cycle. Physiol. Genomics 29:312-319.

Bionaz, M., and J. J. Loor. 2008. Gene networks driving bovine milk fat synthesis during the lactation cycle. BMC Genomics 9:366.

Bionaz, M., J. Osorio, and J. J. Loor. 2015. Nutrigenomics in dairy cows: Nutrients, transcription factors, and techniques. J. Anim. Sci. 93:5531-5553.

Bonnet, M., L. Bernard, S. Bes, and C. Leroux. 2013. Selection of reference genes for quantitative real-time PCR normalisation in adipose tissue, muscle, liver and mammary gland from ruminants. Animal 7:1344-1353.

Capper, J. L., R. G. Wilkinson, A. M. Mackenzie, and L. A. Sinclair. 2007. The effect of fish oil supplementation of pregnant and lactating ewes on milk production and lamb performance. Animal $1: 889-898$

Castro-Carrera, T., P. Frutos, C. Leroux, Y. Chilliard, G. Hervás, A. Belenguer, L. Bernard, and P. G. Toral. 2015. Dietary sunflower oil modulates milk fatty acid composition without major changes in adipose and mammary tissue fatty acid profile or related gene mRNA abundance in sheep. Animal 9:582-591.

Dervishi, E., M. Joy, A. Sanz, J. Álvarez-Rodríguez, F. Molino, and J. H. Calvo. 2012. Forage preservation (grazing vs. hay) fed to ewes affects the fatty acid profile of milk and $C P T 1 B$ gene expression in the sheep mammary gland. BMC Vet. Res. 8:106.

Gama, M. A. S., P. C. Garnsworthy, J. M. Griinari, P. R. Leme, P. H. M. Rodrigues, L. W. O. Souza, and D. P. D. Lanna. 2008. Dietinduced milk fat depression: Association with changes in milk fatty acid composition and fluidity of milk fat. Livest. Sci. 115:319-331.

Gervais, R., J. W. McFadden, A. J. Lengi, B. A. Corl, and P. Y. Chouinard. 2009. Effects of intravenous infusion of trans-10, cis-12 18:2 on mammary lipid metabolism in lactating dairy cows. J. Dairy Sci. 92:5167-5177.

Halmemies-Beauchet-Filleau, A., T. Kokkonen, A. M. Lampi, V. Toivonen, K. S. Shingfield, and A. Vanhatalo. 2011. Effect of plant oils and camelina expeller on milk fatty acid composition in lactating cows fed diets based on red clover silage. J. Dairy Sci. 94:4413-4430.

Harvatine, K. J., and D. E. Bauman. 2006. SREBP1 and thyroid hormone responsive spot 14 (S14) are involved in the regulation of bovine mammary lipid synthesis during diet-induced milk fat depression and treatment with CLA. J. Nutr. 136:2468-2474.

Hussein, M., K. H. Harvatine, W. M. P. B. Weerasinghe, L. A. Sinclair, and D. E. Bauman. 2013. Conjugated linoleic acid-induced milk fat depression in lactating ewes is accompanied by reduced expression of mammary genes involved in lipid synthesis. J. Dairy Sci. 96:3825-3834.

Invernizzi, G., B. J. Thering, M. A. McGuire, G. Savoini, and J. J. Loor. 2010. Sustained upregulation of stearoyl-CoA desaturase in bovine mammary tissue with contrasting changes in milk fat synthesis and lipogenic gene networks caused by lipid supplements. Funct. Integr. Genomics 10:561-575.

ISO. 1999a. Animal feeding stuffs - Determination of moisture and other volatile matter content. Standard 6496:1999. International Organisation for Standardisation (ISO), Geneva, Switzerland.

ISO. 1999b. Whole milk-Determination of milkfat, protein and lactose content-Guidance on the operation of mid-infrared instruments. Standard 9622:1999. International Organisation for Standardisation (ISO), Geneva, Switzerland.

ISO. 2002. Animal feeding stuffs - Determination of crude ash. Standard 5984:2002. International Organisation for Standardisation (ISO), Geneva, Switzerland.

ISO. 2009. Animal feeding stuffs-Determination of nitrogen content and calculation of crude protein content-Part 2: Block digestion and steam distillation method. Standard 5983-2:2009. International Organisation for Standardisation (ISO), Geneva, Switzerland.

Kadegowda, A. K. G., M. Bionaz, L. S. Piperova, R. A. Erdman, and J. J. Loor. 2009. Peroxisome proliferator-activated receptorgamma activation and long-chain fatty acids alter lipogenic gene networks in bovine mammary epithelial cells to various extents. J. Dairy Sci. 92:4276-4289.

Kairenius, P., A. Ärölä, H. Leskinen, V. Toivonen, S. Ahvenjärvi, A. Vanhatalo, P. Huhtanen, T. Hurme, J. M. Griinari, and K. J. Shingfield. 2015. Dietary fish oil supplements depress milk fat yield and alter milk fatty acid composition in lactating cows fed grass silage based diets. J. Dairy Sci. 98:5653-5671.

Ma, L., and B. A. Corl. 2012. Transcriptional regulation of lipid synthesis in bovine mammary epithelial cells by sterol regulatory element binding protein-1. J. Dairy Sci. 95:3743-3755.

Mach, N., A. A. A. Jacobs, L. Kruijt, J. van Baal, and M. A. Smits. 2011. Alteration of gene expression in mammary gland tissue of dairy cows in response to dietary unsaturated fatty acids. Animal 5:1217-1230.

Mele, M., A. Buccioni, F. Petacchi, A. Serra, S. Banni, M. Antongiovanni, and P. Secchiari. 2006. Effect of forage/concentrate ratio and soybean oil supplementation on milk yield, and composition from Sarda ewes. Anim. Res. 55:273-285.

Perfield, J. W., A. L. Lock, J. M. Griinari, A. Saebo, P. Delmonte, D. A. Dwyer, and D. E. Bauman. 2007. Trans-9, cis-11 conjugated linoleic acid reduces milk fat synthesis in lactating dairy cows. J. Dairy Sci. 90:2211-2218.

Peterson, D. G., E. A. Matitashvili, and D. E. Bauman. 2003. Diet-induced milk fat depression in dairy cows results in increased trans-10, cis-12 CLA in milk fat and coordinate suppression of mRNA abundance for mammary enzymes involved in milk fat synthesis. J. Nutr. 133:3098-3102.

Pulina, G., A. Nudda, G. Battacone, and A. Cannas. 2006. Effects of nutrition on the contents of fat, protein, somatic cells, aromatic compounds, and undesirable substances in sheep milk. Anim. Feed Sci. Technol. 131:255-291

Sakai, J., A. Nohturfft, J. L. Goldstein, and M. S. Brown. 1998. Cleavage of sterol regulatory element-binding proteins (SREBPs) at site-1 requires interaction with SREBP cleavage-activating protein. Evidence from in vivo competition studies. J. Biol. Chem. 273:5785-5793 
Shi, H. B., J. Luo, D. W. Yao, J. J. Zhu, H. F. Xu, H. P. Shi, and J. J. Loor. 2013. Peroxisome proliferator-activated receptor-gamma stimulates the synthesis of monounsaturated fatty acids in dairy goat mammary epithelial cells via the control of stearoyl-coenzyme A desaturase. J. Dairy Sci. 96:7844-7853.

Shingfield, K. J., S. Ahvenjärvi, V. Toivonen, A. Äröla, K. V. V. Nurmela, P. Huhtanen, and J. M. Griinari. 2003. Effect of dietary fish oil on biohydrogenation of fatty acids and milk fatty acid content in cows. Anim. Sci. 77:165-179.

Shingfield, K. J., L. Bernard, C. Leroux, and Y. Chilliard. 2010. Role of trans fatty acids in the nutritional regulation of mammary lipogenesis in ruminants. Animal 4:1140-1166.

Shingfield, K. J., M. Bonnet, and N. D. Scollan. 2013. Recent developments in altering the fatty acid composition of ruminant-derived foods. Animal 7S1:132-162.

Spitsberg, V. L., E. Matitashvili, and R. C. Gorewit. 1995. Association and coexpression of fatty-acid-binding protein and glycoprotein CD36 in the bovine mammary-gland. Eur. J. Biochem. 230:872878.

Sukhija, P. S., and D. L. Palmquist. 1988. Rapid method for determination of total fatty-acid content and composition of feedstuffs and feces. J. Agric. Food Chem. 36:1202-1206.

Toral, P. G., L. Bernard, A. Belenguer, J. Rouel, G. Hervás, Y. Chilliard, and P. Frutos. 2016a. Comparison of ruminal lipid metabolism in dairy cows and goats fed diets supplemented with starch, plant oil, or fish oil. J. Dairy Sci. 99:301-316.

Toral, P. G., L. Bernard, C. Delavaud, D. Gruffat, C. Leroux, and Y. Chilliard. 2013. Effects of fish oil and additional starch on tissue fatty acid profile and lipogenic gene mRNA abundance in lactating goats fed a diet containing sunflower-seed oil. Animal 7:948-956.
Toral, P. G., P. Frutos, G. Hervás, P. Gómez-Cortés, M. Juárez, and M. A. de la Fuente. 2010. Changes in milk fatty acid profile and animal performance in response to fish oil supplementation, alone or in combination with sunflower oil, in dairy ewes. J. Dairy Sci. 93:1604-1615.

Toral, P. G., G. Hervás, D. Carreño, A. Belenguer, and P. Frutos. 2015a. Comparison of milk fatty acid responses during fish oiland trans-10 cis-12 18:2-induced milk fat depression in dairy ewes. Anim. Feed Sci. Technol. 210:66-73.

Toral, P. G., G. Hervás, D. Carreño, and P. Frutos. 2016b. Does supplemental 18:0 alleviate fish oil-induced milk fat depression in dairy ewes? J. Dairy Sci. 99:1133-1144.

Toral, P. G., G. Hervás, and P. Frutos. 2015b. Reductions in milk $\Delta^{9}$-desaturation ratios to oral dosing of cobalt-acetate are accompanied by the downregulation of $S C D 1$ in lactating ewes. J. Dairy Sci. 98:1961-1971.

Tsiplakou, E., E. Flemetakis, C. Kalloniati, G. Papadomichelakis, P. Katinakis, and G. Zervas. 2009. Sheep and goats differences in CLA and fatty acids milk fat content in relation with mRNA stearoyl-CoA desaturase and lipogenic genes expression in their mammary gland. J. Dairy Res. 76:392-401.

Vandesompele, J., K. De Preter, F. Pattyn, B. Poppe, N. Van Roy, A. De Paepe, and F. Speleman. 2002. Accurate normalization of real-time quantitative RT-PCR data by geometric averaging of multiple internal control genes. Genome Biol. 3:RESEARCH0034.

Yang, T., P. J. Espenshade, M. E. Wright, D. Yabe, Y. Gong, R. Aebersold, J. L. Goldstein, and M. S. Brown. 2002. Crucial step in cholesterol homeostasis: Sterols promote binding of SCAP to INSIG-1, a membrane protein that facilitates retention of SREBPs in ER. Cell 110:489-500. 